\title{
A Survey Report on the Career Choice, Attitude, Expectations amongst Dental Students - A Cross Sectional Study
}

\author{
Sruthi Susan Abraham ${ }^{1 *}$, Sneha Tarol ${ }^{1}$, Sneha Susan Raju ${ }^{1}$, Anzil K. S. Ali ${ }^{2}$, Kiran Mathai ${ }^{2}$, Supreetha S $^{3}$
}

${ }^{1}$ Intern-St. Gregorios Dental College, Chelad, Cochin, Kerala, India

${ }^{2}$ Senior Lecturer-St. Gregorios Dental College, Chelad, Cochin, Kerala, India

${ }^{3}$ Reader-St. Gregorios Dental College, Chelad, Cochin, Kerala, India

DOI: $10.36347 /$ sjds.2020.v07i07.001

| Received: 06.07.2020 | Accepted: 13.07.2020 | Published: 16.07.2020

*Corresponding author: Dr. Sruthi Susan Abraham

Abstract

Original Research Article

Objective: To assess the drivers behind choice of dental career, student expectations regarding dental career, estimate the prevalence of burnout during the early stages of career and studentship among currently studying and newly graduated general dental practitioners of Kerala using simple questionnaires. Methods: A Cross sectional study was conducted with the study sample being derived from a group of students from the third year, final year, interns and a few clinicians who have completed their course no lesser than 2 years prior. This study exempts the first year and second year group of students. The data for this study was collected using questionnaire schedules using a descriptive survey design with 713 students, over the time period of 45 days at various colleges in and around Kothamangalam, Kerala. The questionnaire was designed such that it includes 18 questions regarding the influences for choice, attitude and expectations regarding one's career. Results: Among the 713 students,, interns and practitioners surveyed $32 \%$ individuals opted for dentistry out of their own personal interests while $40 \%$, chose dentistry due to inability to procure a medical seat. A majority of the participants $(75 \%, n=534)$ have shown to have future plans regarding their careers of which $331(62 \%)$ would like to pursue postgraduation or overseas education programs; pursuing endodontics 109 (33\%), orthodontics $76(23 \%)$, pedodontics $56(17 \%)$ being the more popular choices. The remainder of those not intending to pursue a postgraduation $(\mathrm{n}=112,21 \%)$ would opt for a general practice. Around 371 (52\%) mention change in expectations over the years regarding their career choice and potential outcomes. Following completion of three years under the undergraduate programme a significant $n=285(40 \%)$ opted 'yes' for a career change at this point while the remainder $(n=428,60 \%)$ chose to stay on the same track. Their reasons for opting for a change include 'interest in another subject' $(n=199,28 \%)$, 'Lack of income generated' $(n=36,5 \%)$, and other reasons $(n=93,13 \%)$. Over $50 \%$ did not attempt the question, implying that they were not able to decide their choice yet. Conclusion: This study revealed a rather positive attitude of students towards future career planning and choice with the majority of the group wanting to pursue higher education or working/learning under a clinical setup. The minority of who have decided to opt out was mainly due to lack of interest $\&$ funds.

Keywords: Career choice, dental career, post-graduation, income, career change.

Copyright @ 2020: This is an open-access article distributed under the terms of the Creative Commons Attribution license which permits unrestricted use, distribution, and reproduction in any medium for non-commercial use (NonCommercial, or CC-BY-NC) provided the original author and source are credited.

\section{INTRODUCTION}

Career choice is a complex decision for students since it determines the kind of profession that they intend to pursue in life [1]. As students try to make career choices while in secondary school or be it following a Bachelor's degree programme, they face the problem of matching their career choices with their abilities and school performance $[1,2]$.

Today, one has not only to make do career planning but also exhaustive career research before making a career choice so as to adjust with the evolving socio-economic conditions $[2,3]$.

Most students who are in secondary schools do not have accurate information about opportunities and profession development to help them make appropriate choices [4]. Adding to these, is the factor of increasing unemployment among Indian dental graduates [3, 4].

The ever-increasing number of young dental professionals and the lack of job opportunities, career changes and increasing unemployment has led to the 
proposition of such a study being conducted by our team of interns [5].

The objective of this component of the research programme was to examine the long-term goals and perceived influences on dental students' professional careers [6].

The purpose of this study was to examine factors influencing career choice among dental students in the various colleges in and around Kothamangalam, Kerala [5].

\section{Aim/ Purpose of the Study}

To find out the career expectations and influences among dental students in and around Kothamangalam thus giving an overall representation of the dental profession burnout all over Kerala.

\section{MATERIALS AND METHODS USED}

Study design, population, and duration:

Study was conducted over a period of 45 days from the $2^{\text {nd }}$ of april 2016 to $17^{\text {th }}$ may 2016 at 4 different dental institutes in and around Kothamangalam, Kerala. The total number of individuals part-taking the survey being 713 students and interns.

\section{Official Permission and Ethical Clearance}

The ethical approval for undertaking the study was obtained from the Institutional review board of St. Gregorios dental college.

\section{Informed Consent}

Written consent letter was obtained from each subject prior to undertaking survey questionnaire.

\section{Inclusion Criteria}

- Subjects who were present the days survey being conducted and who were willing at the same for undertaking the survey were included.

- Individuals being selected for the study belonged to a group of students from third year, final year and interns.

\section{Exclusion Criteria}

- Those individuals not willing for the survey

- Study was conducted in such a way that it exempted the first year and second year group of students from the study.

\section{Performa Details}

A Cross sectional study conducted with individuals being selected for the study belongs to a group of students from third year, final year and interns.

Solely on the presumption that the third year, final-year undergraduate students and interns have acquired a more realistic impression of the profession (clinical exposure) than potential entrants, it was of interest to investigate possible differences in the perceptions of dentistry between the different groups.

Thus, the study conducted by exempting the first year and second year group of students from the study.

The study was conducted using a descriptive survey design with 713 students from the third year through the final year BDS and interns of 4 different institutes, over the time period of 45 days at Kothamangalam and Muvatupuzha, Ernakulam District.

The questionnaire was designed such that it included 18 odd questions regarding the expectations, attitude and influences regarding one's career.

\section{Collection of Data and Tabulation \\ Distribution of study $=100 \%$ \\ Where $n=713$}

Table-1: Distribution of subjects according their reason for choosing the profession

\begin{tabular}{|l|l|l|l|l|l|}
\hline parameter & $\begin{array}{l}\text { Family/peers } \\
\mathbf{N}(\%)\end{array}$ & $\begin{array}{l}\text { Personal } \\
\text { interest N(\%) }\end{array}$ & $\begin{array}{l}\text { Money } \\
\mathbf{N}(\%)\end{array}$ & $\begin{array}{l}\text { Inability to procure } \\
\text { medical seat N(\%) }\end{array}$ & $\begin{array}{l}\text { Service } \\
\text { mentality N(\%) }\end{array}$ \\
\hline $\begin{array}{l}\text { Reason for choosing } \\
\text { dentistry }\end{array}$ & $185(26 \%)$ & $228(32 \%)$ & $0(0 \%)$ & $285(40 \%)$ & $15(2 \%)$ \\
\hline
\end{tabular}

Table-2: Distribution of subjects according whether they belong to the a merit or management student category

\begin{tabular}{|l|l|l|}
\hline Parameters & Merit N(\%) & Management N(\%) \\
\hline Merit student/ Management & $335(47 \%)$ & $378(53 \%)$ \\
\hline
\end{tabular}

Table-3: Distribution of subjects according whether they applied for an educational loan

\begin{tabular}{|l|l|l|}
\hline Parameters & Yes N(\%) & No N(\%) \\
\hline Educational loan for UG course & $185(26 \%)$ & $528(74 \%)$ \\
\hline
\end{tabular}


Table-4: Distribution of subjects according whether they belong to the a merit or management student category

\begin{tabular}{|l|l|l|l|l|}
\hline parameters & Parents/family N(\%) & Part time job N(\%) & Scholarship N(\%) & All the above N(\%) \\
\hline Procurement of fund & $620(87 \%)$ & $0(0 \%)$ & $0(0 \%)$ & $71(10 \%)$ \\
\hline
\end{tabular}

*22 (3\%) not mentioned their methods of funding

Table-5: Distribution of subjects according to their definite plans of career/future after BDS

\begin{tabular}{|l|l|l|}
\hline Parameters & Yes N(\%) & No N(\%) \\
\hline Plans regarding career after BDS & $534(75 \%)$ & $179(25 \%)$ \\
\hline
\end{tabular}

Out of the $75 \%(n=534)$ who have career plans

Table-6: Distribution of subjects according to their choice of career/future plans after BDS

\begin{tabular}{|l|l|l|l|}
\hline parameters & PG N(\%) & General practice N(\%) & Complete career change N(\%) \\
\hline Career plans & $331(62 \%)$ & $112(21 \%)$ & $91(17 \%)$ \\
\hline
\end{tabular}

Out of the $62 \%$ individuals $n=331$

Table-7: Distribution of subjects according to their choice a specialty after BDS

\begin{tabular}{|l|l|l|l|l|l|}
\hline Parameter & Endo N(\%) & Ortho N(\%) & Pedo N(\%) & Omfs N(\%) & Other N(\%) \\
\hline Specialty choice & $109(33 \%)$ & $76(23 \%)$ & $56(17 \%)$ & $17(5 \%)$ & $73(22 \%)$ \\
\hline
\end{tabular}

Out of the $62 \%$ individuals $n=442$

Table-7: Distribution of subjects according to their reason for choice of specific specialties

\begin{tabular}{|l|l|l|l|l|}
\hline Parameters & $\begin{array}{l}\text { Able to perform better } \\
\mathbf{N}(\%)\end{array}$ & $\begin{array}{l}\text { Personal interest } \\
\mathbf{N}(\%)\end{array}$ & $\begin{array}{l}\text { Money } \\
\mathbf{N}(\%)\end{array}$ & $\begin{array}{l}\text { Family/peers } \\
\mathbf{N}(\%)\end{array}$ \\
\hline Reason for choosing so. & $99(30 \%)$ & $86(26 \%)$ & $133(40 \%)$ & $14(4 \%)$ \\
\hline
\end{tabular}

Table-8: Distribution of subjects according to whether they would opt for general practice alone

\begin{tabular}{|l|l|l|}
\hline Parameters & Yes N(\%) & No N(\%) \\
\hline General practice alone & $26 \%$ & $74 \%$ \\
\hline
\end{tabular}

Table-9: Distribution of subjects according to whether or not they would opt for general practice alone

\begin{tabular}{|l|l|l|}
\hline Parameters & Yes N(\%) & No N(\%) \\
\hline Any change in expections & $342(48 \%)$ & $371(52 \%)$ \\
\hline
\end{tabular}

Table-10: Distribution of subjects according to where they would opt to practice dentistry

\begin{tabular}{|l|l|l|l|l|}
\hline Parameters & Kerala N(\%) & Within India N(\%) & Middle east N(\%) & West N(\%) \\
\hline Place opt for Practice & $370(52 \%)$ & $143(20 \%)$ & $64(9 \%)$ & $93(13 \%)$ \\
\hline
\end{tabular}

*43 (6\%) would opt for other places

Table-11: Distribution of subjects according to reasons why subjects chose to work in a particular country/place

\begin{tabular}{|l|l|l|l|l|}
\hline parameters & Money N(\%) & Facilities N(\%) & Comfort N(\%) & Family N(\%) \\
\hline Reason for choice & $100(14 \%)$ & $107(15 \%)$ & $192(27 \%)$ & $229(32 \%)$ \\
\hline Other reason in N(\%) $85(12 \%)$ & \multicolumn{3}{|l}{} \\
\cline { 1 - 3 }
\end{tabular}

Table-12: Distribution of subjects according to whether this career is profitable or not

\begin{tabular}{|l|l|l|}
\hline Parameters & Yes N(\%) & No N(\%) \\
\hline Expect to make profit & $506(71 \%)$ & $207(29 \%)$ \\
\hline
\end{tabular}

Table-13: Distribution of subjects according to their working preference

\begin{tabular}{|l|l|l|l|l|}
\hline parameters & Under an institution N(\%) & Private N(\%) & Partnership N(\%) & Govt. service N(\%) \\
\hline Working preference & $163(23 \%)$ & $199(28 \%)$ & $87(12 \%)$ & $264(37 \%)$ \\
\hline
\end{tabular}


Table-14: Distribution of subjects who desire and don't desire a career change

\begin{tabular}{|c|l|l|}
\hline Parameter & Yes N(\%) & No N(\%) \\
\hline Career change & $285(40 \%)$ & $428(60 \%)$ \\
\hline
\end{tabular}

Table-15: Distribution of subjects according to the reason for opting out

\begin{tabular}{|l|l|l|l|}
\hline Parameters & Lack of income & Dislike for profession & Other \\
\hline Reason for career change & $36(5 \%)$ & $199(28 \%)$ & $93(13 \%)$ \\
\hline$*$ Not attempted & $385(54 \%)$ & & \\
\hline
\end{tabular}

*refer table 14 - 428(60\%) said no implying, 385(54\%) belong to the 428(60\%)

When $n=428$ and 385 not attempted, remaining 43 individuals are sure of their choice of career.

Table 16: Distribution of subjects according to whether or not practice is feasible in their area

\begin{tabular}{|l|l|l|}
\hline Parameters & Yes N(\%) & No N(\%) \\
\hline Feasibility of practice & $242(34 \%)$ & $471(66 \%)$ \\
\hline
\end{tabular}

\section{DISCUSSION AND REPORT}

Among the total number of 713 students being subjected to the questionnaires 185 (26\%) chose dentistry as a career option due to family/peer pressure, $228(32 \%)$ out of their own personal interests, 285 (40\%) due to inability to procure a medical seat either financially or on a merit basis and $15(2 \%)$ out of the service mentally and almost none with an outlook for making money (Table-1).

In a similar study conducted by Meera et al., in Tamil Nadu regarding their career perspectives majority opted for the dental career due to family/peer pressure or due to the inability to procure a medical seat [7].

The subjects being surveyed consisted of 335 (47\%) merit students and 378 (53\%) management students who procured their funds from varied sources: Of which 185 (26\%) took an educational loan for their completion of study.

Other means of obtaining finance included students being dependent on parents/family for funding $620(87 \%), 71(10 \%)$ on the basis of other funding and $22(3 \%)$ who've not mentioned their varied financial sources.

Most students, a majority of $75 \%$ have shown to have certain future plans regarding their career and remaining $25 \%$ being indefinite about their future plans.

This being in contrast to a study conducted among final year Malaysian dental students which indicated that over $89 \%$ of respondents had definite plans regarding their future [8].
Out of the $75 \%(n=535)$ who have career plans

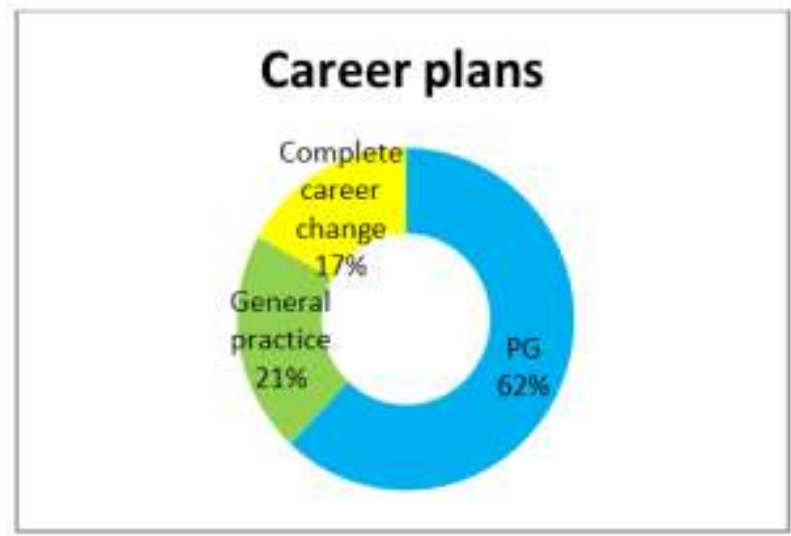

Among the $534(75 \%)$ students who have definite plans, $331(62 \%)$ would like to pursue postgraduation or any sort of overseas education programme and $112(21 \%)$ would opt for general practice (refer Table-5).

Similarly, in the previously mentioned study conducted by Meera et al., approximately 59\% (where $\mathrm{n}=265$ ) of the respondents indicated that they planned to enter practice immediately; $28 \%$ planned to pursue specialty training after graduation [7].

On comparing with a study conducted in Malaysia by Che Musa et al., among dental undergraduate students; Career expectations and influences among dental student in Malaysia, there appears to be a higher level of interest in pursuing further studies and specialization amongst our subjects [9].

When they only seem to have $59 \%(n=356)$ of subjects wanting to specialize we seem to have a figure of $331(62 \%)(n=534)$ wanting to specialize [9]. 
Our study subjects on the other hand, the remainder $91(17 \%)$ would like a complete career change. This is being notable as there is no reference to such a choice among the Malaysian students $[8,11]$.

A study from the "Milieu in Dental Schools and Practice" by Naidu et al reveals that there is however a correlation between dental students wanting to opt out and seek other lines of work $[10,11]$.

Amongst the $331(62 \%)$ that would like to pursue post-graduation or overseas education, 109 $(33 \%)$ would choose endodontics, 76 (23\%) for the department of orthodontics, $56(17 \%)$ candidacy for pedodontics, $17(5 \%)$ for oral maxilla facial surgery and $73(22 \%)$ of individuals for other departments.

\section{Further specialization where $n=331(62 \%)$}

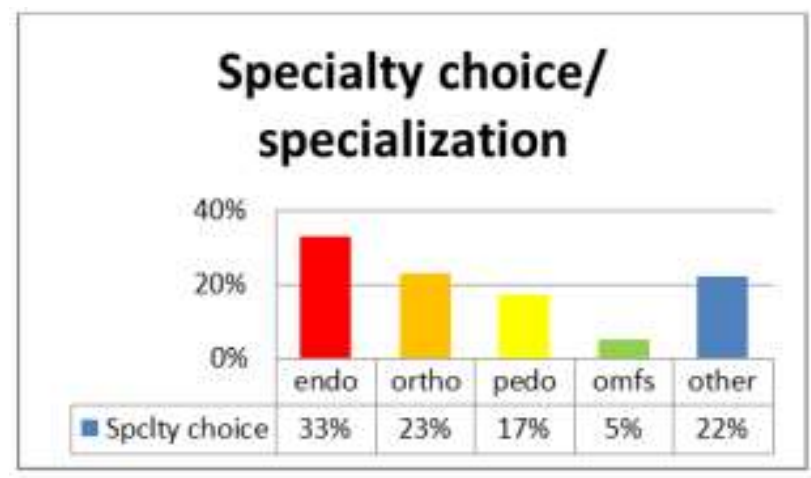

Similar and comparable results are seen in a study; "Dental Students Perceptions and Factors influencing specialty and career choices". Where in the study was used to evaluate dental students perceptions of dental specialties and identifying the factors that governed the decision making [12].

Most of the people who are considering doing post-graduation chose that particular specialty because of money $132(40 \%)$ and the intuition that their capabilities would be best put to use in that particular department, this being 99 ( 30\%) [13].

Other reasons for their choice such as out of genuine interest for the subject being $86(26 \%)$ and finally $14(4 \%)$ of the candidates due to pressure from peer groups and family members.

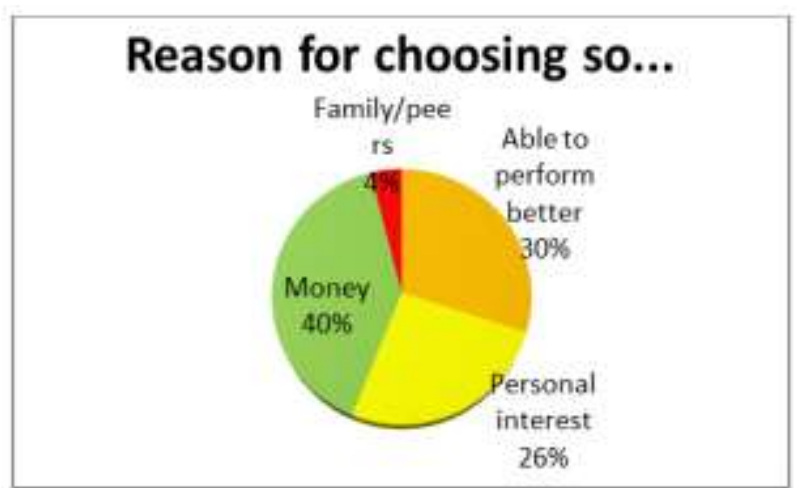

On comparing with other studies, it is notable that there are also other multiple guiding factors associated with choosing a particular specialty. These include; prior dental school experience/predoctoral training and faculty influence. These factors were not evaluated during this study [13].

But almost all studies reveal that certain specialties do tend to be more in demand such as orthodontics and oral maxilla facial surgery being at the more popular front. The results are comparable to a number of studies published in the journal of dental education [12-14].

It was notable that certain individuals chose to be satisfied with setting up a general practice of their own, this accounts for 185 (26\%) of the total number of individuals who have a definitive career option.

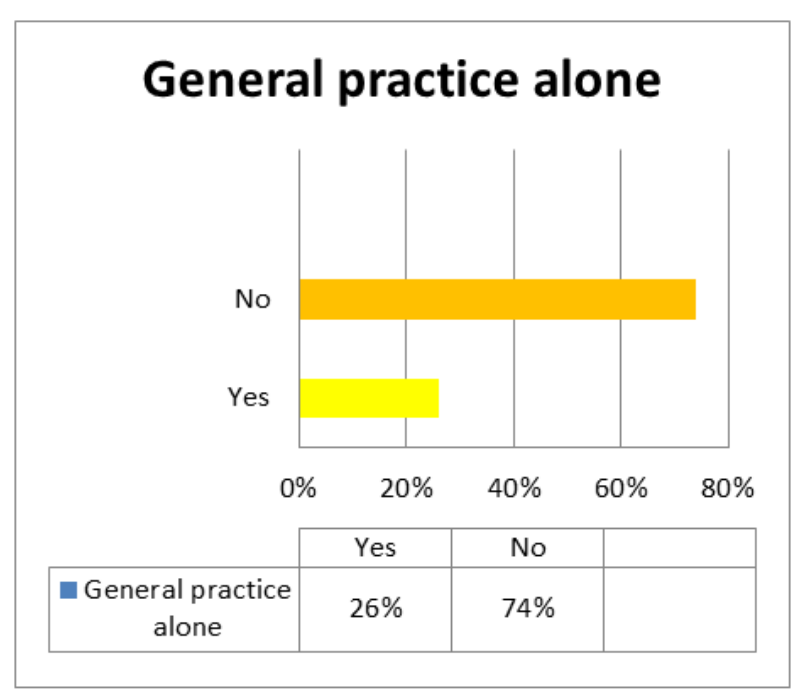

A review article "Job satisfaction among general practitioners" mentions the clear cut phenomenon of burn out due excessive supply of medical practitioners and limited demand for the same [15]. 
Mentioning the added factors of little recognition, need for time to establish one's self, lack of appreciation etc [15].

Despite all of this a notable 185 (26\%) have opted to settle for general practice. The probable reasons include; stress being associated with highest for job dissatisfaction. Other parameters appear to be rather irrelevant with such groups of individuals.

Another major factor appears to be the funding for tuition and future career options- a do with what you have approach could be another possible reason [16].

\section{Change in Expectations over the Years}

When enquired whether individuals had any change in expectations over the years regarding their careers, when asked $371(52 \%)$ said that their expectations had changed.

\section{change in expectations}
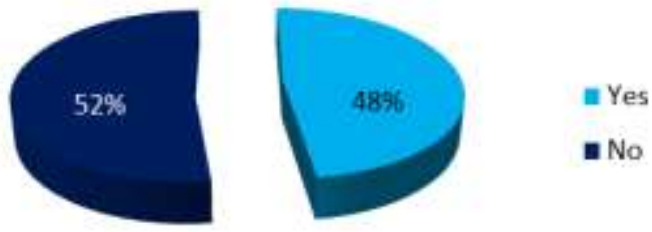

Wanting to continue in the same line of career is highly associated with the like factor where in subjects are comfortable with their environment and patients [9].

A study from the "Milieu in Dental Schools and Practice" by Naidu et al reveals that there is however a correlation between dental students wanting to opt out and seek other lines of work [10].

These reasons discussed mainly include wanting to quit due to failures, fear of failures, fear of competition, various stresses, burnout and financial overbearing $[10,11]$.

From our study most students have shown a trend to stay within their localities in Kerala, a majority of $370(52 \%)$.

Some wanted to pursue a career elsewhere: $143(20 \%)$ individuals anywhere else in India other than Kerala, 64 (9\%) in the Middle East, 93 (13\%) in the west and $43(6 \%)$ opt for other places.

There are local jobs for dental undergraduates and postgraduates to practice in the city but the quality of opportunities in terms of salary is not good. This may be attributed to accounting for $39 \%$ wanting to go abroad to work.

The added factors of a handsome pay, better quality of life etc. is attracts our young individuals [17].

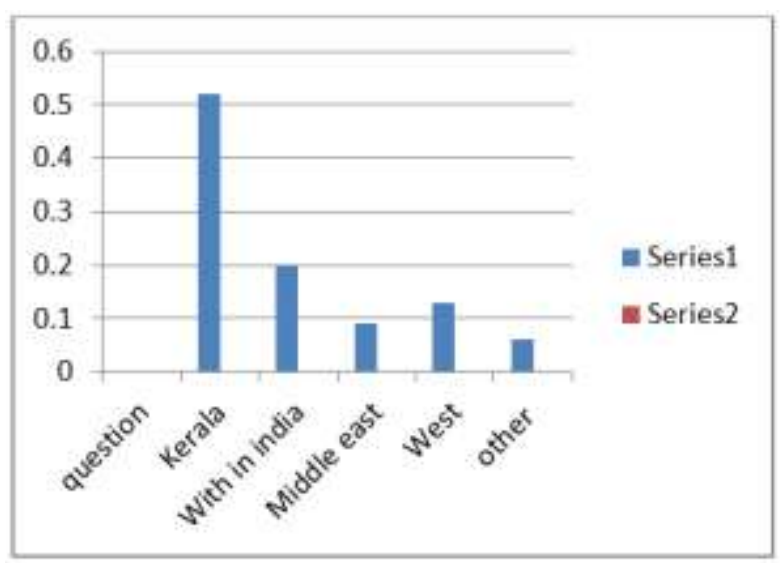

It can be deduced that majority Reason family interests; 229 (32\%) and Working comfort; 192 (27\%) for deciding to practice in preferable places. Other minor reasons include the availability of better facilities being $107(15 \%)$ of subjects and $100(14 \%)$ for the money, A minority of 85 (12\%) for other reasons.

\section{Reason for choosing}

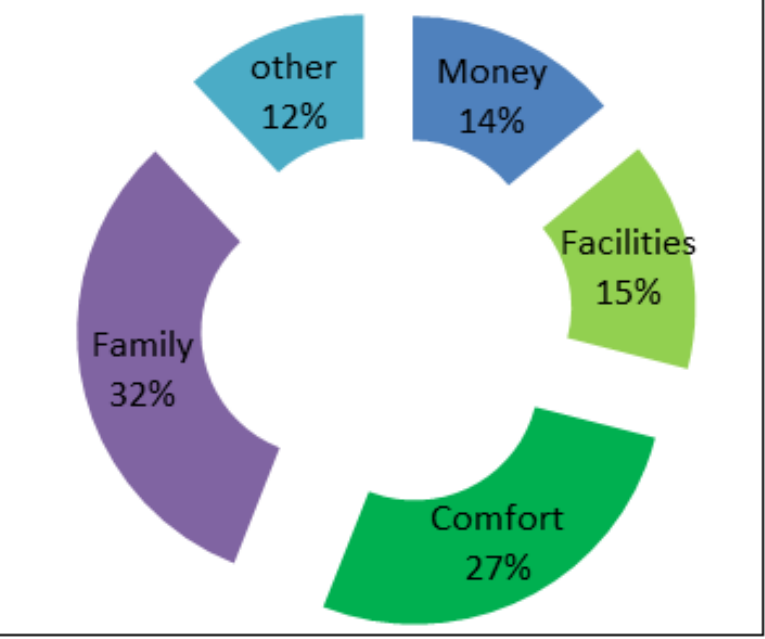

When asked about their expectations in making a profit out of this line of career $506(71 \%)$ said yes and 207 (29\%) said no (refer: Table-12).

Among the people who wish to practice dentistry preferences for working under an institution includes 163 (23\%) and for a private setup practice 199 $(28 \%)$ of individuals said yes. 
A minor group of $87(12 \%)$ individuals would prefer the liaison of a Partnership. But a staggering 264 $(37 \%)$ would rather go into the Government sector.

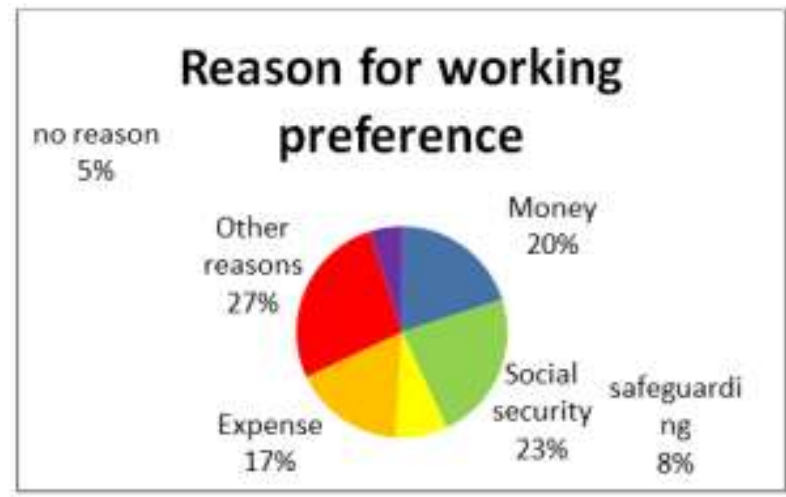

The reasoning for their particular choices includes a small $8 \%$ prefer being safeguarded under an institution and an even smaller 5\% have no particular reason for such a choice.

However, most people state social security and income as their reasons. It appears to be the money for $20 \%$ individuals and social security for $23 \%$ individuals.

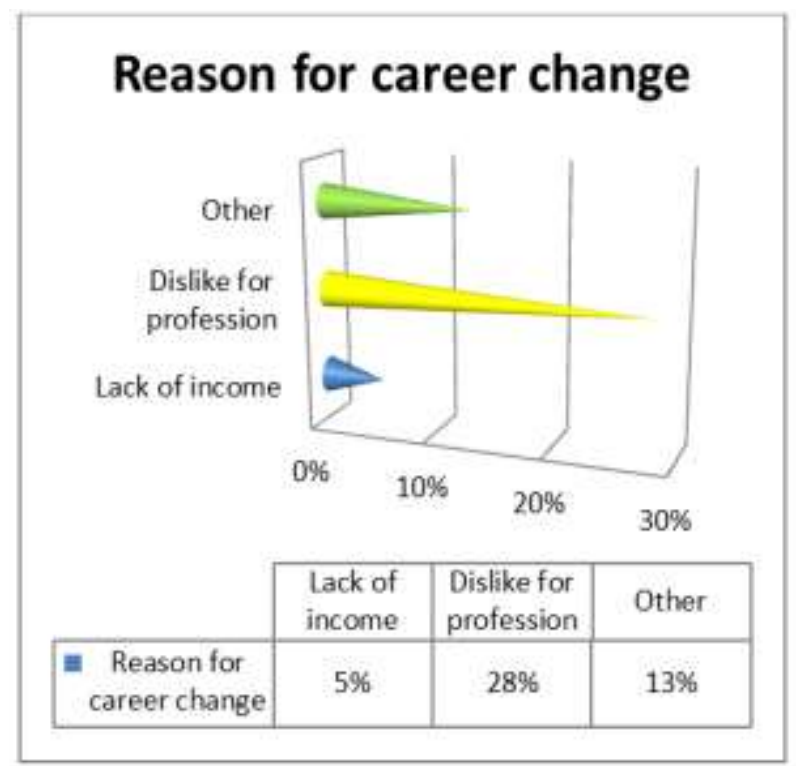

Some find it too expensive to establish a private setup and this accounts for a $17 \%$ of individuals and remainder $27 \%$ state other reasons for their decision.

Following completion of three years under the undergraduate programme a significant $40 \%$ opted yes for a career change at this point and $60 \%$ for no.

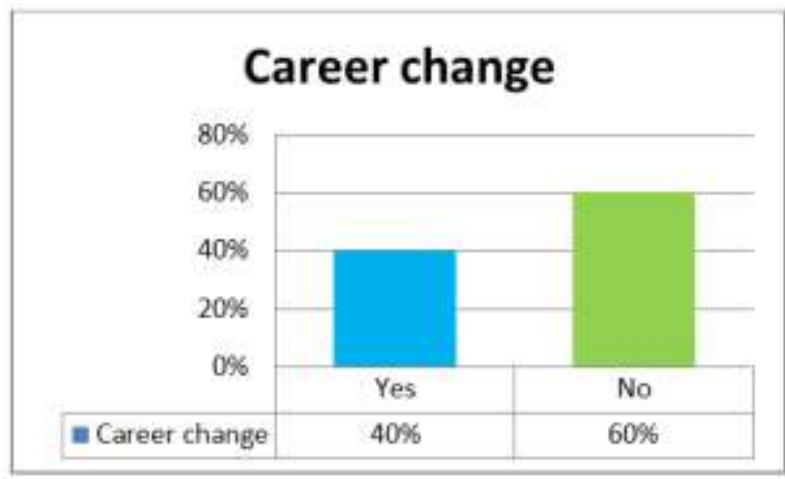

Their reasons for opting for a change $(n=285)$ include the Lack of income generated by $14(5 \%)$, a significant $80(28 \%)$ because of their interest in another subject and 37(13\%) mention other reasons. People who've not attempted being 154 (54\%) implying that $54 \%$ where $\mathrm{n}=285$ not being able to decide and still contemplating their choice.

From the numbers, 242 (34\%) individuals have a general opinion that their practice setup in their locality would not be feasible nor will it flourish given the number of practice setups in their areas but 471 $(66 \%)$ however strongly believe that their setup would be successful.

\section{Limitations of the Study}

As far as to our knowledge this is the first survey of its kind in Kerala which makes its comparison difficult.

The prior dental school experience or predoctoral training and faculty influence were not evaluated during the study.

\section{CONCLUSIONS}

Student career choices are influenced by numerous factors including outcome expectancies, individual variants such as gender, personal interests, learning experiences, environmental factors etc.

Outcome expectancies were the most influential factors. Family members and peers have also shown influence in individuals.

Today in general, Dental graduates cannot or are not able to practice independently because they cannot afford the infrastructure and work as assistants under seniors with paltry salary and foreign shores are not easy either. Long term career plans of new graduates commonly embrace opportunities for professional development as well as personal issues such as work/life balance and financial income.

By this study we have redeemed our knowledge through the survey on 'Career expectations and influences among dental students' $\&$ is our honor to present this work to you all. 


\section{ACKNOWLEDGEMENT}

We sincerely thank the Department of Public Health Dentistry, the Principal and all the students who part took in the survey.

\section{REFERENCES}

1. Gorter RC, Storm MK, Te Brake JH, Kersten HW, Eijkman MA. Outcome of career expectancies and early professional burnout among newly qualified dentists. International dental journal. 2007 Aug;57(4):279-85.

2. Blustein DL. The role of career exploration in the career decision making of college students. Journal of counseling psychology, 1989; 35:297-300.

3. Betz NE, Serling D. Fear of commitment and career decision-making self-efficacy. Unpublished manuscript, Ohio State University. 1995.

4. Arulmani G, Nag-Arulmani S. Work orientations and responses to career choices: Indian regional survey. WORCC-IRS-Draft Report, National Consultation on Career Psychology (NCCP). 2006:1-65.

5. Kumar VP, Dodamani A, Kerudi V, Shirahatti R, Telka S. Perceived sources of stress among Indian dental students. Journal of Indian Association of Public Health Dentistry. 2011 Jul 1;9(17):171.

6. Skelly AM, Fleming GJ. Perceptions of a dental career among successful applicants for dentistry compared with those of fifth-year dental students. Primary Dental Care. 2002 Aug 1;9(2):41-6.

7. Priya BM, Shivakumar V, Anitha V, Shanmugam M, Tejasri G, Vidhu S. Career perspective among dental professionals in Tamil Nadu. Journal of Education and Ethics in Dentistry. 2014 Jul $1 ; 4(2): 61$.

8. Nashleanas BM, McKernan SC, Kuthy RA, Qian F. Career influences among final year dental students who plan to enter private practice. BMC Oral Health. 2014 Dec 1;14(1):18.
9. Che Musa MF, Bernabé E, Gallagher JE. Career expectations and influences among dental students in Malaysia. International dental journal. 2016 Aug;66(4):229-36.

10. Naidu RS, Adams JS, Simeon D, Persad S. Sources of stress and psychological disturbance among dental students in the West Indies. Journal of dental education. 2002 Sep;66(9):1021-30.

11. Atkinson JM, Millar K, Kay EJ, Blinkhorn AS. Stress in dental practice. Dental update. 1991 Mar;18(2):60-4.

12. Dhima M, Petropoulos VC, Han RK, Kinnunen T, Wright RF. Dental students' perceptions of dental specialties and factors influencing specialty and career choices. Journal of dental education. 2012 May;76(5):562-73.

13. Shin JH, Kinnunen TH, Zarchy M, Da Silva JD, Chang BM, Wright RF. Factors influencing dental students' specialty choice: a survey of ten graduating classes at one institution. Journal of Dental Education. 2015 Apr;79(4):369-77.

14. Sam G, Alghmlas AS, Alrashed MI, Alaskar ZA. Working environment and specialty of choice chosen by the dental students at Prince Sattam Bin Abdulaziz University, Saudi Arabia: A crosssectional study. Journal of International Society of Preventive \& Community Dentistry. 2016 Apr;6(Suppl 1):S1.

15. Van Ham I, Verhoeven AA, Groenier KH, Groothoff JW, De Haan J. Job satisfaction among general practitioners: a systematic literature review. The European journal of general practice. 2006 Jan 1;12(4):174-80.

16. Gilmour J, Stewardson DA, Shugars DA, Burke FJ. An assessment of career satisfaction among a group of general dental practitioners in Staffordshire. British dental journal. 2005 Jun;198(11):701-4.

17. Sikdar P. "Dental graduates look towards foreign shores", times of India article, TNN, September 7, 2016. 